\title{
多層盛溶接による熱応力・ひずみに関する熱弾塑性解析*
}

\author{
一累層して加熱冷却をうける帯板の熱応力およびひずみについて一
}

\author{
佐藤邦彦** 瀬尾健二*** 岩井健治**** 高橋大輔*****
}

\section{Thermal elasto-plastic analysis on stress and strain induced in weld metal during multi-pass welding*}

by Kunihiko Satoh**, Kenji Seo***, Kenji Iwai**** and Daisuke Takahashi*****

\begin{abstract}
This paper is concerned with the elasto-plastic analysis of thermal stresses and strains in weld metal of multi-pass butt weld. Analysis is performed based on the incremental theory of thermo-elasto-plasticity under one dimensionaly distributed temperature. Numerical calculations are made for two kinds of weld joint as shown in Figs. 1(b), (c), each of which corresponds to the behavior of the transverse and longitudinal section of weld joint respectively.

Assumptions are made for heat flow that a rectangular distribution of initial temperature is given at the start of each pass and heat flow occurs only in y-direction. Another initial condition is also applied to the calculations that a line heat source is given at the start of each pass as shown in Fig. 9.

From the calculations are estimated successfully transient thermal stress and plastic strain distributions. Effects of weld conditions on residual stress and strain are clarified. Relations between plastic strain in back surface and angular distortion under several weld conditions are also obtained.
\end{abstract}

\section{1. 緒旁}

溶接による熱応力あるいは变形に関する従来の研究の 大部分は溶接部およびその近傍の細部を除く巨視的な応 力あるいは変形を取扱っており ${ }^{11}$ ，溶接割れ現象などに 関連して特に重要となる溶接部およびその近傍の局部的 応力あるいはひずみについては未知の点が多い. 特に多 層盛溶接で生じる局部的な応力およびひずみに関しての 解析的研究は全く行なわれていないといってよい状態で ある。

本研究では多層盛溶接の際に溶接部に発生する局部的 応力・ひずみ挙動を明らかにして多層盛溶接で生じる溶 接割れの力学的条件を考察する為の基礎的資料を得るこ とを目的として，模型化した溶接継手について熱弾塑性 解析を行なった。

熱弾望性解析問題の数值解析法として, 最近有限要素 法の利用が行なわれるようになってきだつ3). この方法 は一般性を有し非常に有力な手段であるがパラメータ整

\footnotetext{
*原稿受付 昭和48年 3 月 8 日（48年度春季全国大会にて発表）

**正 買 大阪大学溶接工研学究所 Member, Osaka

***正 員 大阪大学工学部 Member, Faculty of Engnee. ring Osaka University University, Welding Research Institute

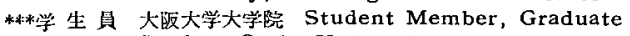
Student Oaska University,

*****氺 具 新日本製鉄 (株) Member, Nippon Steel Corporation
}

理が行ないにくく，また計算が非常に複雑となり，多層 盛溶接で生じる熱応力・ひずみ解析には多大な計算時間 を要するという歎点がある。

そこで本研究では後に述べるように問題を模型化し， 辻4によって与えられたひずみ增分理論による一次元熱 弾塑性解析法を適用して計算を行なった。

\section{2. 解 析 方 法}

\section{1 多屬盛溶接の一次元モデル化}

多首盛溶接としては Fig. 1(a) に示すような T形開先 の突合せ溶接継手で, 溶接は瞬間的に温度 $T_{0}$ の溶接金 属がのど厚 $a$ づつ順次盛られていくようなモデルを想 定する. この場合溶接線に直角方向 ( $x$ 力向) 応力に対 しては母材部分の抵抗を無視し，Fig. 1(b) に示すよう な周边自由な帯板の上に初期温度 $T_{0}$ の帯板を順次重ね ていくような一次元問題として解析した。一方溶接線方 向 ( $z$ 方向) 応力に対しては綐曲がり変形がほとんじ生 じないよ考えられるので Fig. 1(c) に示すような曲率を 零とした帯板の積み重ね問題として解析した。

\section{2 温度分布}

Fig. 1(b) に示すように任意ののど厚 $C_{0}$ まで溶接金 属が盛られた上に, 時刻 $t=0$ で温度 $T_{0}$ の溶接金属が $a$ だけ盛られてのよ゙厚が $C$ になった時, 任意時刻 $\mathbf{t}$ に 


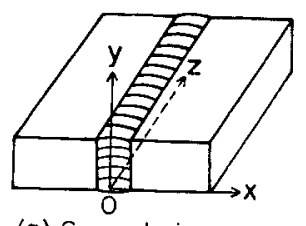

(a) General view
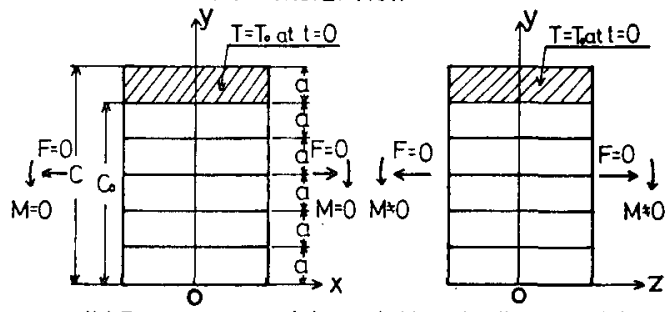

(b) Transverse model

Fig. 1. Explanation of multi-pass weld joint model in which a rectangular distribution of initial temperature is given at the start start of each pass.

おける温度分布 $T(y)$ は下縁 $(y=0)$ に扔ける熱の反 射を考慮すると（1）式で与えられる，ただし温度は $\boldsymbol{y}$ 方向にのみ伝導するものとしている.

$$
\begin{aligned}
T_{(y)}= & \frac{T_{0}}{2} \sum_{n=1}^{\infty}\left\{\phi\left(\frac{2(n-1) c-y+c+a}{2 \sqrt{k t}}\right)\right. \\
& \left.-\phi\left(\frac{2(n-1) c-y+c-a}{2 \sqrt{k t}}\right)\right\} \\
& +\frac{T_{0}}{2} \sum_{n=1}^{\infty}\left\{\phi\left(\frac{2 n c+y-c+a}{2 \sqrt{k t}}\right)\right. \\
& \left.-\phi\left(\frac{2 n c+y-c-a}{2 \sqrt{k t}}\right)\right\}
\end{aligned}
$$

ただし $\phi(z)=\frac{2}{\sqrt{ } \pi} \int_{0}^{z} e^{-\alpha^{2}} d u, k:$ 熱拡散率

こてで次のような無次元変数を導入する.

$$
\left.\begin{array}{cll}
\tau=\alpha T / \varepsilon_{Y_{0}}, & \tau_{0}=\alpha T_{0} / \varepsilon_{Y_{0}}, & \eta=y / c \\
\eta_{0}=a / c, & \kappa=2 \sqrt{k t} / c
\end{array}\right\}
$$

ただし $E:$ ヤング率 $\alpha:$ : 楾膨脹係数

$$
\begin{aligned}
& \sigma_{Y_{0}}: \text { 基準温度における材料の降伏応力 } \\
& \varepsilon_{Y_{0}}=\sigma_{Y_{0}} / E
\end{aligned}
$$

\begin{tabular}{|c|c|c|c|}
\hline & Item & Mark & Nondimension \\
\hline & $\begin{array}{l}\text { Time } \\
\text { Location } \\
\text { Stress } \\
\text { Yield Strain } \\
\text { Strain } \\
\text { Plastic strain } \\
\text { Temperature } \\
\text { Moment }\end{array}$ & $\begin{array}{l}\mathrm{t} \\
\mathrm{y} \\
\sigma \\
\varepsilon_{Y} \\
\varepsilon \\
\varepsilon_{P} \\
\mathrm{~T} \\
\mathrm{M}^{*}\end{array}$ & $\begin{array}{c}k=2 \sqrt{\kappa \mathrm{t}} / \mathrm{C} \\
\eta=\mathrm{y} / \overline{\mathrm{C}} \\
\mathrm{s}=\sigma / \sigma_{Y_{0}} \\
\mathrm{e}_{Y}=\sigma_{Y} / \varepsilon_{Y_{0}} \\
\mathrm{e}=\varepsilon_{/ \varepsilon_{Y 0}} \\
e_{p}=\varepsilon_{p} / \varepsilon_{Y_{0}} \\
\tau=\alpha \mathrm{T} / \varepsilon_{Y_{0}} \\
\mathrm{M}=\mathrm{M} / \mathrm{C}^{2} \sigma_{Y}\end{array}$ \\
\hline 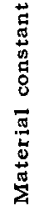 & $\begin{array}{l}\text { Thermal diffusivity } \\
\text { Young's modulus } \\
\text { Thermal expansion } \\
\text { Yied strength depe- } \\
\text { ndent on temperature } \\
\text { Strain hardening } \\
\text { Yield strength }\end{array}$ & $\begin{array}{l}\frac{b}{\mathrm{E}} \\
\alpha \\
\mathrm{q} \\
\mathrm{h} \\
\sigma_{Y}\end{array}$ & $\begin{array}{c}- \\
- \\
\mathrm{n}=\mathrm{q} \varepsilon_{Y_{0} / \alpha} \\
\mathrm{m}=\mathrm{h}_{\varepsilon_{Y 0}} \\
\mathrm{~s}_{Y}=\sigma_{Y / \sigma_{Y_{0}}}\end{array}$ \\
\hline
\end{tabular}

（2）式を用いると（1）式は（3）式のように書き換 えられる。

$$
\begin{aligned}
\tau(y)= & \frac{\tau_{0}}{2} \sum_{n=1}^{\infty}\left\{\phi\left(\frac{2(n-1)-\eta+1+\eta_{0}}{\kappa}\right)\right. \\
& \left.-\phi\left(\frac{2(n-1)-\eta+1-\eta_{0}}{\kappa}\right)\right\} \\
& +\frac{\tau_{0}}{2} \sum_{n=1}^{\infty}\left\{\phi\left(\frac{2 n+\eta-1+\eta_{0}}{\kappa}\right)\right. \\
& \left.-\phi\left(\frac{2 n+\eta-1-\eta_{0}}{\kappa}\right)\right\}
\end{aligned}
$$

Table 1 Variables used in this paper

$\times 10^{-7}$ 以下になるまで行なっている，また温度がほぼ 一様な分布（表面之裹面のての差が 0.016 以下）にるる と，それ以後は一様に冷却するとみなしている．

\section{3 熱弾塑性解析}

熱弾塑性解析法としては辻による増分理論》ををそのま ま適用している.なおこてで用いる変数は Table 1 K 一括して示している.

材料の降伏応力 $\left(\sigma_{Y}\right)$ の温度依存性とひずる硬化低存 性は（4）式のように仮定している.

$$
\left.\begin{array}{ll}
T \leq \frac{1}{8} \text { の時 } & \sigma_{Y}=\sigma_{Y_{0}}(1-q T)\left(1+h \bar{\varepsilon}_{p}\right) \\
T>\frac{1}{q} \text { の時 } & \sigma_{Y}=0
\end{array}\right\}(4)
$$

ただし $q$ : 降伏応力の温度依存性を示す材料定数

$h:$ 降伏応力のひずみ硬化依存性を示す材料定 数

$\bar{\varepsilon}_{p}=\Sigma\left|\Delta \varepsilon_{p}\right|$

$\Delta \varepsilon_{p}:$ 塑性ひずみ増分

（4）式を無次元化すると（5）式となる.

$\left.\begin{array}{ll}\tau \leq 1 / n \text { の時 } & S_{Y}=e_{Y}=(1-\dot{n} \tau)\left(1+m \bar{e}_{p}\right) \\ \tau>1 / n & \text { の時 }\end{array}\right\}$

ただし $\quad \bar{e}_{p}=\Sigma\left|\Delta e_{p}\right|, \Delta e_{p}=\Delta \varepsilon_{p} / \varepsilon_{Y_{0}}$

また Fig. 1(b)，(c) に示すような周辺自由および曲率零 なる拘束条件の帯板の下端から任意距離 クだけ離れた 点において，時刻 $\kappa_{i}$ から $\kappa_{i+1}$ までの $\Delta \kappa$ なる時間間 隔におけるひずみの変化量は（6）式のように無次元化 して与えられる。

$$
\begin{array}{ll}
\Delta e=\Delta a+\Delta b \cdot \eta-\Delta \tau & \text { (周辺自由の之き) } \\
\Delta e=\Delta a-\Delta \tau & \text { （曲率零に拘束の之き）｝}
\end{array}\}
\end{array}
$$

ただし 
$\Delta a=\frac{-L_{3 E} \cdot \Delta P+L_{2 W} \cdot \Delta Q}{L_{2 E^{2}}-L_{H} \cdot L_{3 H}}, \Delta b=\frac{L_{2 H} \cdot \Delta P-L_{F} \cdot \Delta Q}{L_{2 E}{ }^{2}-L_{H} \cdot L_{3 E}}$

曲率 $B=\Sigma \Delta b$ (周辺自由の之き)

$\Delta a=\frac{\Delta P}{L_{B}}$ (曲率雾に拘束のとき)

$\Delta P=\int_{0}^{1} g \cdot \Delta \tau \cdot d \eta-\int_{0}^{1}(1-g)\left(s g n \Delta e_{Y}\right) d \eta$

$\Delta Q=\int_{0}^{1} g \cdot \Delta \tau \cdot \eta d \eta-\int_{0}^{1}(1-g)\left(s g n \Delta e_{Y}\right) \eta d \eta$

$L_{H}=\int_{0}^{1} g d \eta, \quad L_{2 B}=\int_{0}^{1} g \eta d \eta, L_{3 B}=\int_{0}^{1} g \eta^{2} d \eta$

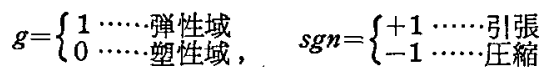

$\Delta \tau$ : 時刻 $\kappa_{i}$ 加ら $\kappa_{i+1}$ までの間での温度変化

また（5）式から降伏応力の変化量は（7）で与えられ る.

$$
\Delta e_{Y}=m\left(1-n \tau_{i}\right)\left|\Delta e_{p}\right|-n\left(1+m \bar{e}_{i}\right) \Delta \tau
$$

また降伏条件之応力一ひずみ関係式から（8）式が得ら れる.

$$
\begin{aligned}
& \left.\begin{array}{l}
S_{i}{ }^{2}<\left\{\left(1-n \tau_{i}\right)\left(1+m \bar{e}_{i}\right)\right\}^{2} \text { または } \\
S_{i}= \pm\left\{\left(1-n \tau_{i}\right)\left(1+m \bar{e}_{i}\right)\right\} \text { で } \Delta e \pm\left(1+\bar{e}_{i}\right) n \Delta \tau \lessgtr 0
\end{array}\right\} \\
& \text { ならば } \Delta e_{p}=0 \quad g=1 \\
& S_{i}= \pm\left\{\left(1-n \tau_{i}\right)\left(1+m \bar{e}_{i}\right)\right\} \text { で } \Delta e \pm\left(1+m \vec{e}_{i}\right) n \Delta \tau \vdots 0 \\
& \text { ならば } \\
& \Delta e_{p}=\frac{\Delta e \pm\left(1+m e_{i}\right) n \Delta \tau}{1+m\left(1-n \tau_{i}\right)}, \quad g=0
\end{aligned}
$$

各点の $\Delta e$ と $\Delta e_{p}$ が得られると応力増分は (9) 式か ら得られる。

$$
\Delta S=\Delta e-(1-g) \Delta e_{p}
$$

なお（6）式，(7) 式，（8）式において $S_{i}, \tau_{i}, \bar{e}_{i}$ は時刻 $\kappa=\kappa_{i}$ に求ける応力, 温度, 塑性ひずみ量を表 わしている。

実際の数值計算においては，鋼の多層盛溶接の場合を 想定して次のような数值を採用した.

降伏応力の温度伐存性（(Fig. 2 参照)：

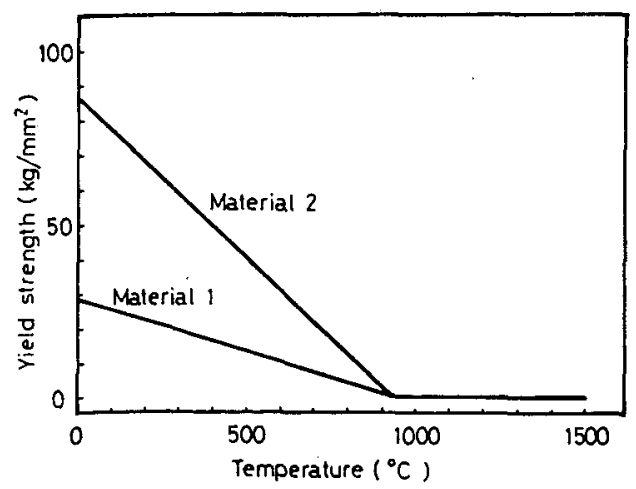

Fig. 2. Temperature dependency of yield strength of the materials.
材料 $1 \quad \sigma_{Y_{0}} \cdot q=\frac{28.7}{932}$ (すなわち $n=0.1$ )

材料 $2 \sigma_{Y_{0}} \cdot q=\frac{86.1}{932}$ (すなわち $n=0.3$ ）

材料のひずみ硬化依存性 : $m=0.0137$

$$
\begin{array}{ll}
\text { 線胈脹係数 : } & \alpha=1.47 \times 10^{-50} \mathrm{C}^{-1} \\
\text { 溶接金属の初期温度 : } & T_{0}=1500^{\circ} \mathrm{C}
\end{array}
$$

なお溶接金属の初期温度と溶接入熱との相関について は後に3. 4 項で考察している.

\section{3. 過渡的熱応力と塑性ひずみ}

\section{1 応力および塑性ひずみ分布}

初層溶接は一樣に自由収縮し，応力およびひずみは生 じないむのとして 2 層目の溶接金属が置かれた瞬間から それが冷えきるまでの応力, 塑性ひずみおよび变形様相 の時間的変化化つて示す.

溶接線に直角方向 ( $x$ 方向) 断面での時間経過に伴な う变形様相を Fig. 3 曲線Bで示している. 因の横軸に は 2 層目の溶接金属が置かれた瞬間からの経過時間を, 綐軸には曲率をそれぞれ無次元量で示している．初期段 階では表面側に凸の変形をするが熱が裹面の方へ伝わる 之共に逆の变形を生じ,裹面側に凸の変形となる.そして この変形は断面の温度が一様になるまで続くが, 一様温 度として表裹面の温度差がその温度の $2 \%$ 以内之考える と, 計算上は $\kappa \fallingdotseq 1.50$, また $0.5 \%$ 以内とすると $\kappa \fallingdotseq 1.85$ で変形が終わるてとになる5). いっぽう溶接線方向 $(\boldsymbol{z}$ 方向）断面に関してはこのような変形は拘束されている ため，ての变形に対応して Fig. 3 曲線 M に示すよう

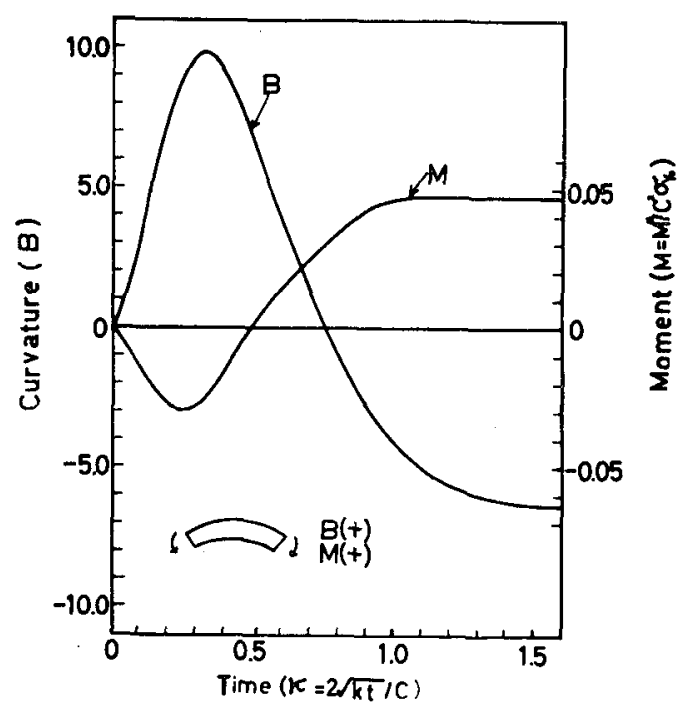

Fig. 3. Transient curvature in transverse section and bending moment in longi- tudinal section after the second pass weld. 
な曲げモーメントが発生する。

次に断面内で発生する熱応力の過渡的変化を Fig. 4 (a) (b) に示している.図の縦軸は応力值を,图中の数字は 経過時間をそれぞれ無次元量で，また横軸には初層裏面 加らの距離を示している. 図 (a) に示す溶接線に直角方

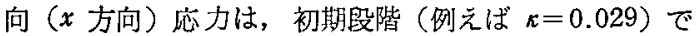
は 2 層目溶接金属内で引張，初層表面（図中 $\mathrm{a}$ 点）近傍 で大きな圧縮, 中央部で引張, 衰面で圧縮応力となって いる. しかし時間の経過とともに各部の応力值は逆転 し，最終的 $(\kappa=\infty)$ 飞残留応力として，2 層目表面で は压縮, 中央部㧍よび裹面で引張, 初層表面で引張, 中 央部で圧縮, 裹面で引張応力が生じている.

一方溶接線方向 ( $z$ 方向)応力は図 (b) に示すように,

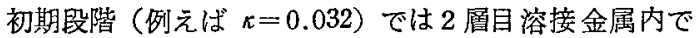

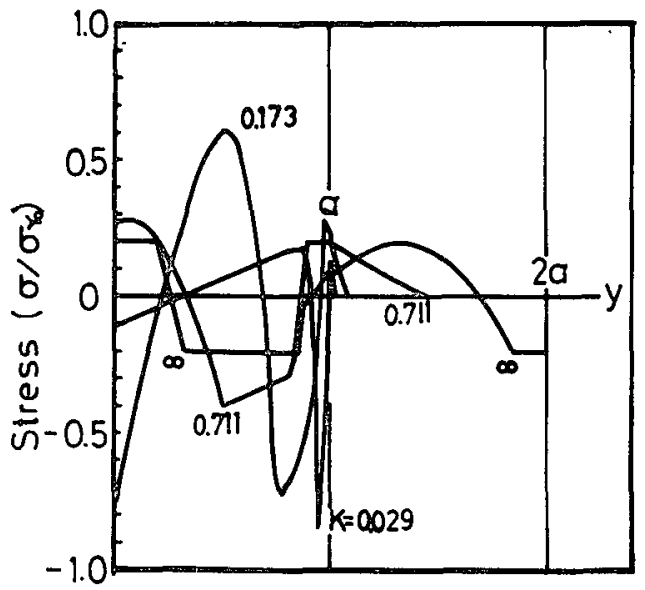

(a) Transverse section

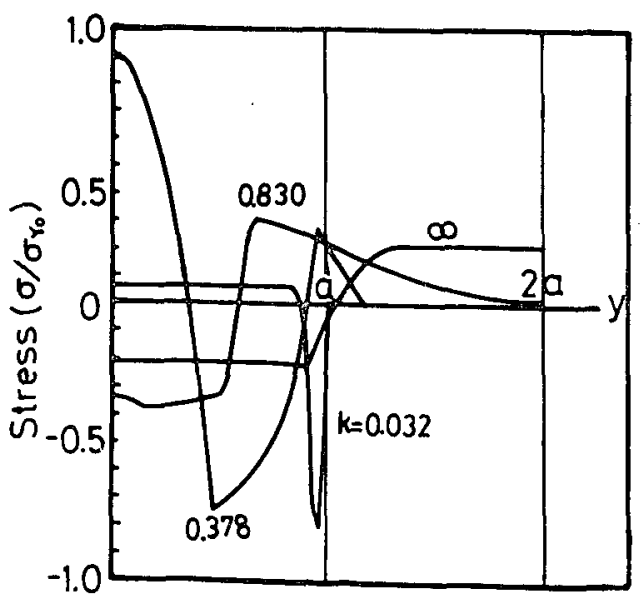

(b) Longitudinal section

Fig. 4. Transient stress distributions after the second pass weld.
引張, 初層表面近傍で压縮, 中央部および寒面で引張応 力となるが，時間経過ととむに初首表面近傍で引張，中 央で王縮, 嗰面で引張の応力值に変化し, 最終的 $(\kappa=$ の）には残留応力として 2 層目には引張，初層には王縮 応力が生じる、なお Fig. 4 で残留応力值が基準温度で の降代応力に比べてかなり小さな値となっているのは表 裏面が一様になる温度が高くなっているためである。

Fig. 5 (a) (b) にはこの時の塑性ひずみ量（本論文にお いては，塑性ひずみ量は $932^{\circ} \mathrm{C}$ 以下で受けたひずみ量 の代数和とする）の変化する様相を示している，溶接 線直角方向断面では 2 層表面および初層表面に圧縮の塑

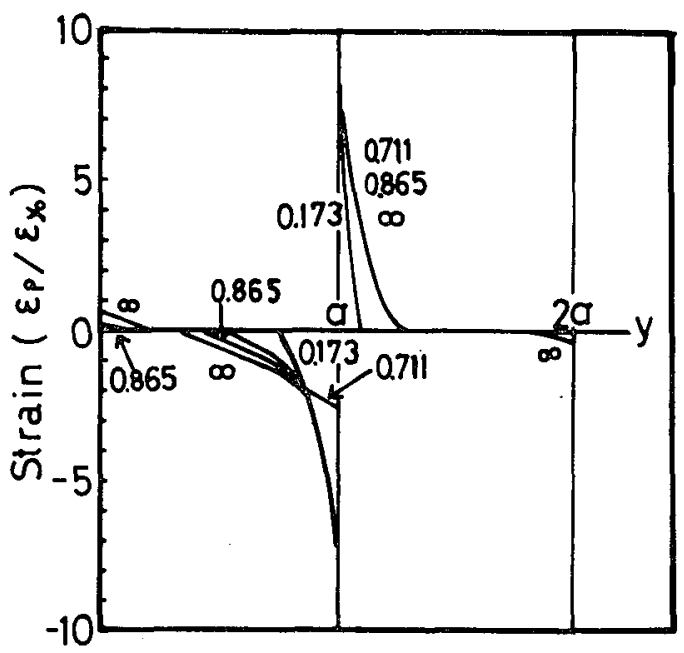

(a) Transverse section

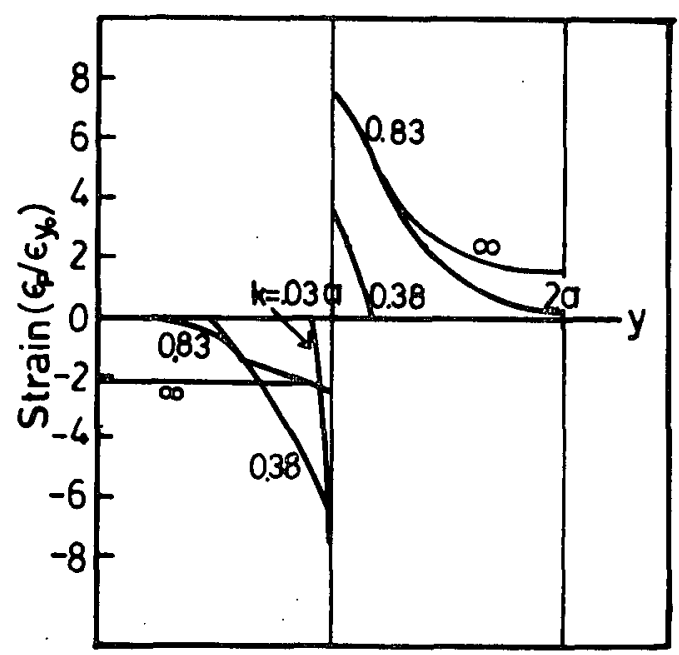

(b) Longitudinal section

Fig. 5. Transient plastic strain distributions after the second pass weld. 
性ひずみ、 2 層裏面および初層裹面には引張の塑性ひず みが生じている，溶接線方向では 2 層目に引張塑性ひず み，初層には王縮塑性ひずみが生じている。

\section{2 前の層に存在する残留応力の影響}

次にこのような残留応力あるいは残留望性ひずみが存 在する上に 3 層目の溶接金属を盛った時の過渡的応力変 化を Fig. $6(\mathrm{a})$, (b) に，塑性ひずみの変化を Fig. 7 (a), (b) に示している，乙の場合 2 層溶接による残留応力 （図中破線で示す）が存在しているため初期段階では応 力分布はかなり複雑な分布をするが熱の伝導とともに再 分布する。

2 層まで残留応力が生じないとして，3 層溶接を行な った場合の残留応力分布を Fig.6 中に 1 点鎖線で示し ており，乙机と比皎すると残留応力分布には 2 層目の残 留応力の影響はほとんど現われていないことがわかる。 また塑性ひずみについては 2 層目までの残留塑性ひず み(Fig. 7 中に破線で示す) の上に， 3 層目の溶接によ る塑性ひずみが加わるような分布傾问を示している。

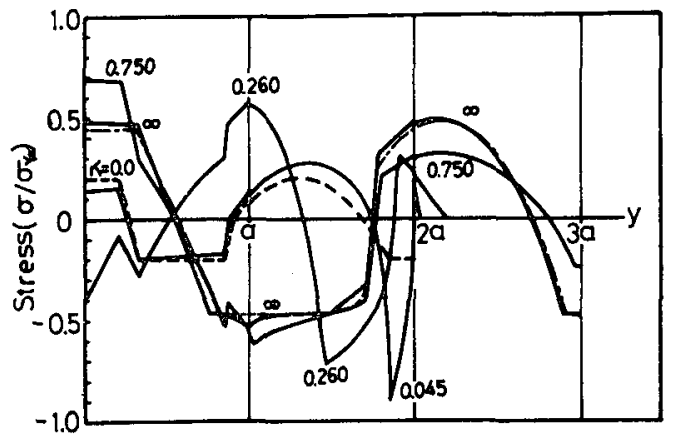

(a) Transverse section

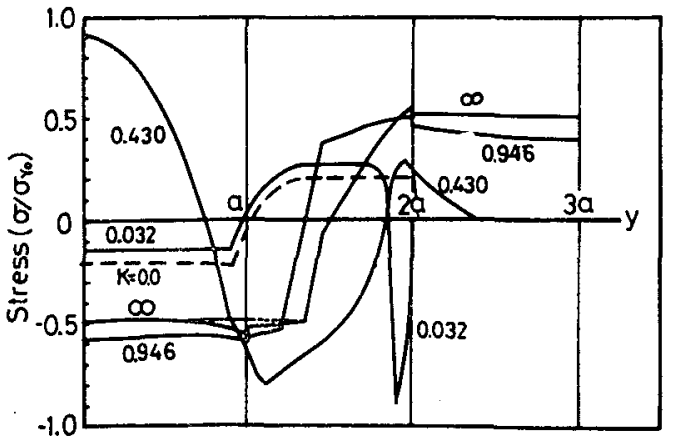

(b) Longitudinal section

Fig. 6. Transient stress distributions after the third pass weld.

\section{3 熱応力の時間的変化}

Fig. 8 は主要位置の応力推移を示したもので, Fig. 8 (a) は溶接線直角方向, Fig. 8 (b) は溶接線方向の場合で

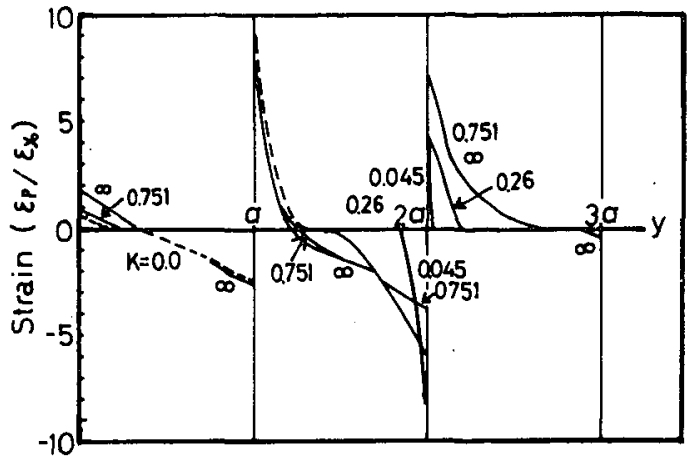

(a) Transverse section

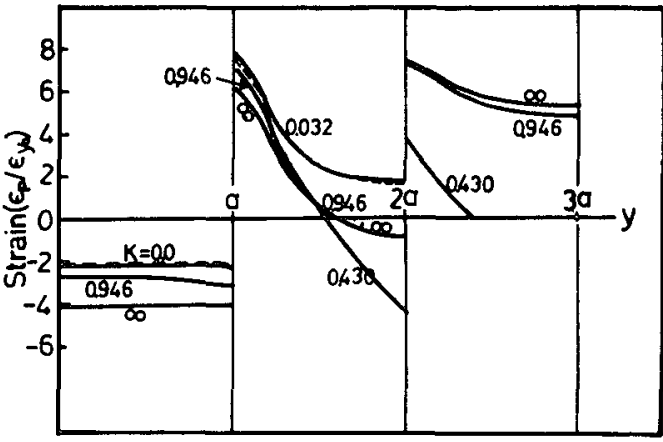

(b) Longitudinal section

Fig. 7. Transient plastic strain distributions after the third pass weld.

ある．図の縦軸は応力を，横軸に各層溶接開始からの経 過時間をそれぞれ無次元量で示している.

Fig. 8 (a) の左半分に示した 2 層目溶接後の応力推移 に上ると, 初層裏面は曲線 1 亿示すように初期段階では 王縮応力であるが時間の経過とともに引張に移り $x=0.8$ で極大となった後，最終的には断面の平均温度上杽にお ける降伏応力に対応した応力值になる. 初首之 2 層の境 界部（境界より $a / 40$ 離れた位置での他力を図示してい る）では，曲線 2，3亿示すように初期段階において 初層側は圧縮， 2 首側には引張応力が生じるが，時間の 経過とともに耐者はほぼ等しい応力值になる，2 層目の 表面は最初は高温状態を持続するため $几 \doteqdot 0.85$ まで応 力は零であるが，曲線 4 亿示すように温度降下につれて 王縮応力が発生し, 最終的には断面の平均温度上昇の降 伏強度に等しい応力が残留する。

Fig. 8 (a) 右半分に示した 3 層目を溶接後の応力推移 あ 2 層溶接時と類似の傾向を示している.

Fig. 8 (b) には溶接線方向応力の推移を示しており, この場合曲げ変形が拘束されるため，表裏面については 溶接線直角方向の場合之応力の正負が逆になっている. しかし各層の境界部については曲げモーメントの影響が 


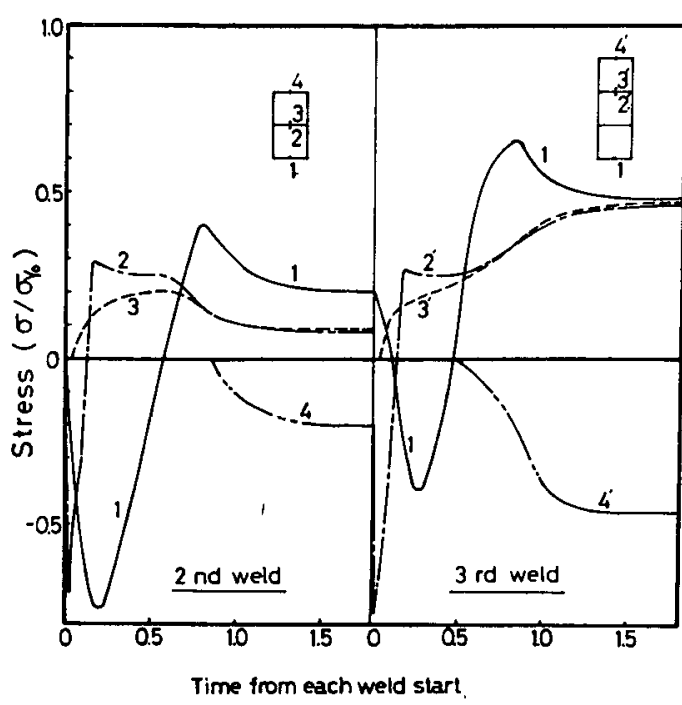

(a) Transverse section

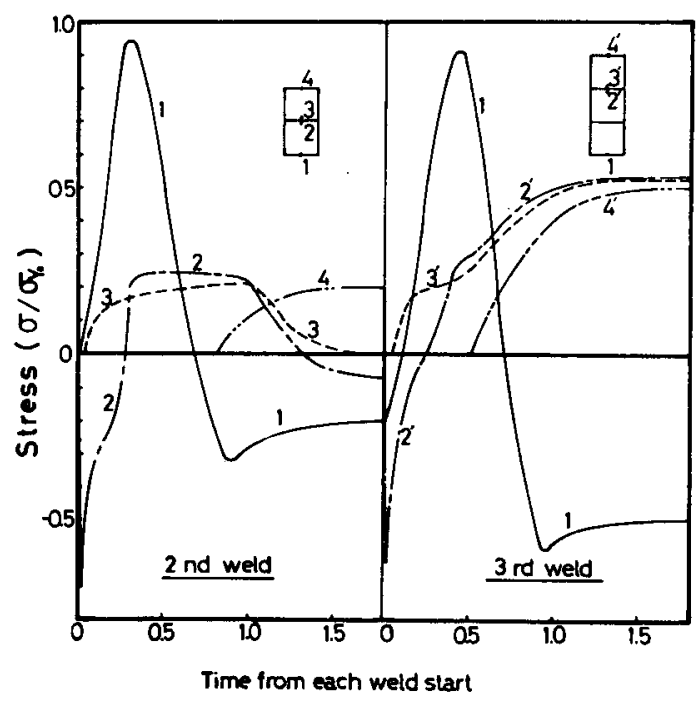

(b) Longitudinal section

Fig. 8. Stress cycle at several locations in weld metal.

小さいため，溶接線直角方向の場合と類似の傾向となっ ている.

\section{4 二次元熱伝導による温度分布を与えた場合の計 算}

以上に示した解析では無次元量を用いているが，てれ を実際の溶接に対応させる意味において，例えば 1 首で 盛られる溶接金属の深さと巾を共に $10 \mathrm{~mm}$ と仮定して 入熱量を計算すると, 約 6300 joùle/cm の入熱しか与 えられていないことになる。これは実際の溶接において 普通に与えられる入熱よりかなり小さく，実際の溶接之
の対応を考えることができない．乙れは実際の溶接では 熱は母材部へあ二次元的に伝導していくのに対して本解 析ではこれを考虑していないととによる，そこで次に熱 伝導のみを二次元的に考え応力解析についてはてれまで と同樣に一次元解析を行なった結果について示す.

今 Fig. 9 に示すように $N$ 層目の溶接金属が置かれた 場合を考える．との時 $N$ 層目の溶接金属の表面飞瞬間 的に Qjoule/cm の線状熱源が与えられたすのと考え， このような線状熱源による $y$ 軸上の温度が $x$ 方向に一 様に分布するものと仮想して計算を行なってみた．との 場合 $N$ 層目の裹面(図中 $\eta_{n}$ 点) が溶融温度 $\left(1500^{\circ} \mathrm{C}\right) \mathrm{K}$ なった瞬間を初期状態としてそれ以後について計算を行 なっている. ここで溶接金属ののど厚 $a$ は線状熱源 $Q$ による $N$ 層目の裹面の点の最高到達温度が丁度 $1500^{\circ} \mathrm{C}$ に等しくなるようにきめる．溶接金属ののど厚 $a$ をて のように決めておくと温度分布に関しては相似則が成立 し，したがって入熱が変化しても個々に計算する必要が ない. 今入熱を $21000 \mathrm{joule} / \mathrm{cm}$ とするとのど厚 $a=$ $0.88 \mathrm{~cm}$ となる。

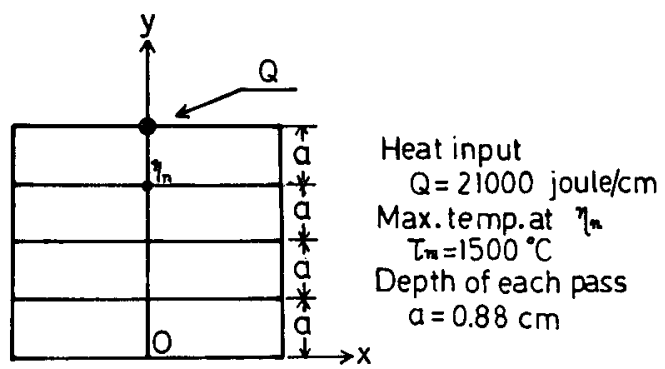

Fig. 9. Multi-pass weld joint model in which a line heat source is given at the start of each pass.

熱伝尊をこのように考えると，2 層溶接後断面が一様 になる温度は約 $650^{\circ} \mathrm{C}$ となる．これを 2 項で述べた矩 形状熱源の初期温度 $\left(T_{0}\right)$ 亿换算すると $1300^{\circ} \mathrm{C}$ とな り, 前述のように $T_{0}$ として $1500^{\circ} \mathrm{C}$ を与えるととは, やや過大に与えたととになる。

Fig. 10 (a) には 2 層目を置いた時の溶接線に直角方向 断面内での過渡的応力の変化する様子を示している.乙 れを Fig. 4 (a) 亿示す場合と比較すると, 初期段階の応 力分布はかなり異なっているが時間の経過とともによく 似た傾向を示すようになり，残留応力分布はほぼ等しく なっている．乙のととは Fig. 10 (b) と示す 2 層目およ び 3 層目の残留応力分布を見るとよりはっきりと理解す るとよができる。

すなわち図中実線は熱伝導を二次元的に考えた場合の 残留応力分布を，破線は Fig. 4(a) および Fig. 6(a) K 


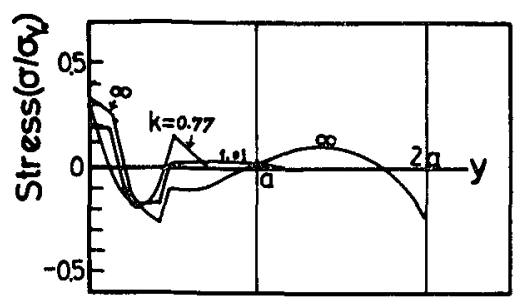

(a) Transient stress

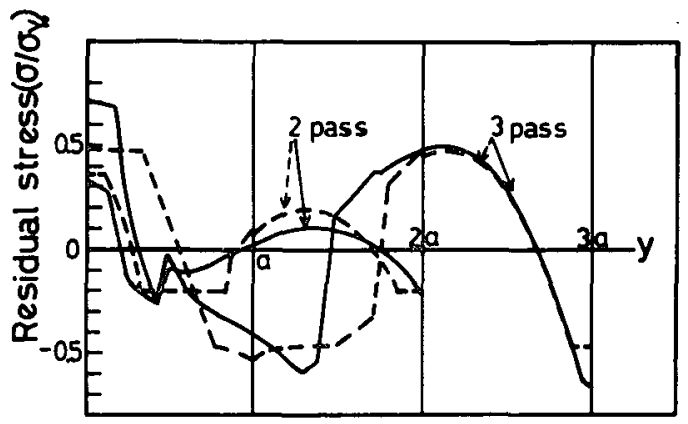

(b) Residual stress distribution

Fig. 10. Transient and residual stress distributions of a model as shown in Fig. 9.

示しだ一次元熱伝導による解析結果であり，両者はほぼ 等しい応力分布となっている．したがって矩形状熱源の 初期温度がやや高すぎるてとは残留応力分布に関しては さして問題にならない之考えられる，そてで以下の計算 は矩形状熱源で初期温度 $1500^{\circ} \mathrm{C}$ の条件で行なった。

\section{4. 残留応力および塑性ひずみにおよぼす溶接 条件の影響}

\section{1 層数の影響（各層の入熱一定の場合）}

Fig. 11 (a) (b) には 6 層まで溶接金属をおいた時に各 層で生じる残留応力分布を示している，図 (a) は溶接線 江直角方向 ( $x$ 方向) の応力分布を，図 (b) は溶接線方 向 $(z$ 方向) の応力分布を示している. 図 (a) をみると 初層裹面は表襄面の温度が一様になった時点では，いず れの層数においても降伏しており，平均温度上昇に対応 した降伏強度に等しい引張応力が残留している，いっぽ う最終層表面では層数が少ない時は曲がり变形のため瓦 縮の残留応力が存在しているが，乙れは層数の増加と之 もに小さくなり引張侧へと移る僋向にある。これは㕌数 が増すほど曲げ剛性が大きくなり，曲げ変形が生じにく くなるためである．またこの応力分布において， 3 層目 以後はいずれの場合す最終層のすぐ下の層の表面側に大 きな引張残留応力が存在している。乙の引張残留応力 は，小林ら $\left.{ }^{6}\right)$ が HY 80 鋼の多層盛溶接において認めて

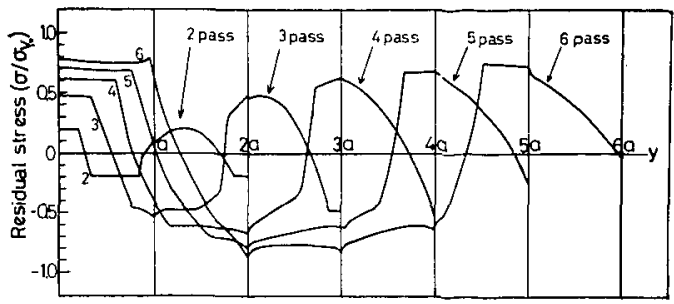

(a) Transverse section

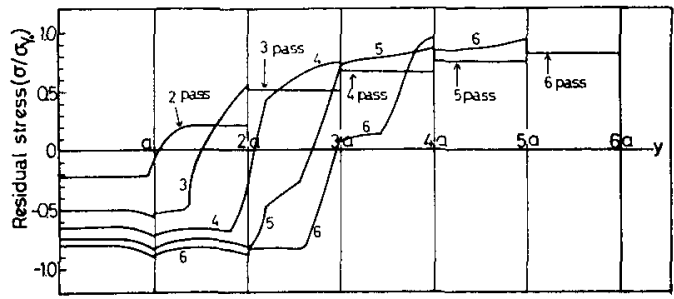

(b) Longitudinal section

Fig. 11. Residual stress distributions of multipass weld model as shown in Fig. 1.

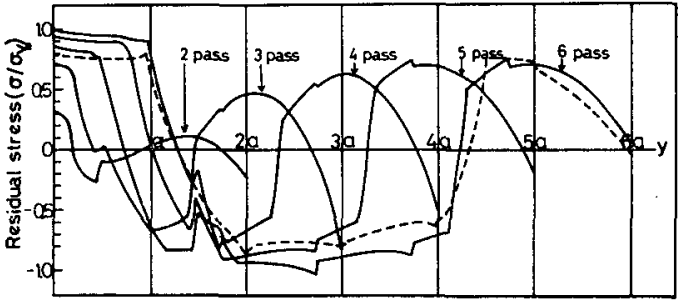

Fig. 12. Residual stress distributions of a model as shown in Fig. 9.

いる再熱割れに対する力学的要因の一つであろう。

一方図 (b) に示す溶接線方向応力はいずれの首数にお いてあ，初層側半分では圧縮残留応力,最終層側半分では 引張残留応力となっている，そして図 (a) の場合と同様 に居数が多くなると最終層のすぐ下の層の表面側にかな り大きな引張残留応力が存在している。て机はサブマー ジアーク溶接による多層盛溶接で生じる横割れ7) 上応力 的な面で関連づけられるのではないかと思われる。

また Fig. 12 には 3.4 項で述べたのと同様な考え方 で二次元熱伝導による温度分布を与えた場合について溶 接線に直角方向断面の残留応力分布を示している，図中 破線で示したものは Fig. 11 (a) に示した計算結果から 6 層溶接後の残留応力分布を転記したものであり，両者 を比較すると非常によく似た傾向を示しているととがわ 加る。

Fig. 13 (a) (b) には 6 層まで溶接金属をおいた時に， 各層で生じる塑性ひずみ量の分布を示している，図 (a) 


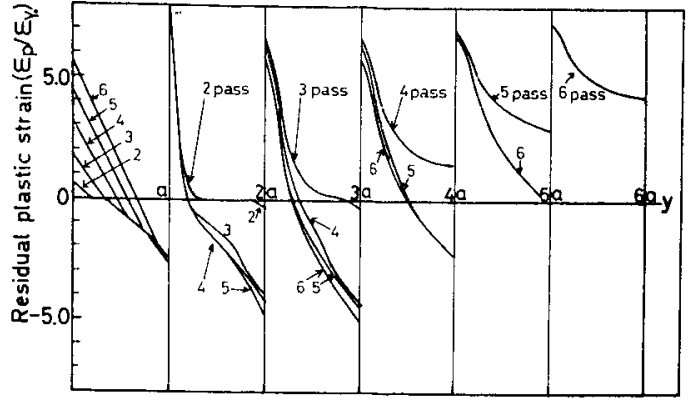

(a) Transverse section

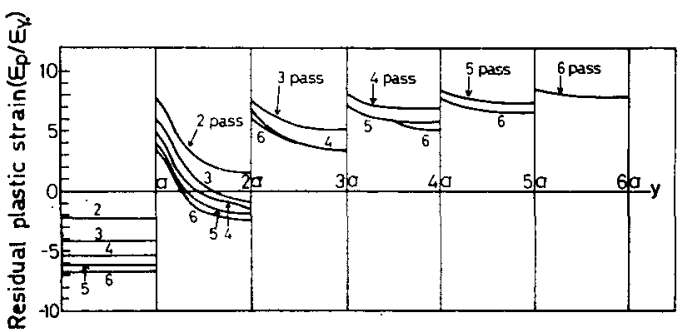

(b) Longitudinal section

Fig. 13. Residual plastic strain distributions of multi-pass weld model as shown in Fig. 1.

は溶接線仁直角方向（ $x$ 方向）断面，因 (b) は溶接線方 向 $(z$ 方向) 断面についてのものである. 図 (a) をみる といずれす各層の裹面で大きな引張の塑性ひずみが残留 している.そして初層裹面の塑性ひずみは Fig. 14 に 示すように層数が増すととあにほぼ直線的に增加してい ることがわかる，一方 Fig. 13 (b) では初層には圧縮塑 性ひずみ，最終層では引張塑性ひずみが残っている。

\section{2 層数と入熱の組み合せの影簍}

Fig. 15 (a) (b) は一定のど厚 $c$ が与えられた場合に, これを 3 層, 4 層および 6 層で溶接を完了させる場合の 溶接線直角方向断面における残留応力分布と塑性ひずみ 分布を示している、一般に少ない層数で溶接を完了した 場合（大入熱溶接）は残留応力は小さくなり，また初層

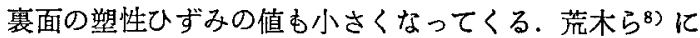
よると剝離割れ試験でるられるルートからの割㣗は，同 じのぞ厚 $20 \mathrm{~mm}$ を溶接するのに手溶接 5 層 7 パスよ り，MIG 溶接 4 層盛りの方が割れ率が小さく、サブマ ージアーク溶接 3 層盛りになるといっそう割れ率は低下 するとの報告がなされている，乙れは昖散性水素量ある いは溶接法のちがいなどが主要因かと思われるが，応力 的な面からあ大入熱小数盛りの方が割れに対して有效で あることがうかがわれる。

\section{3 予熱およひ嶱間温度の影㫪}

次に多層盛溶接における熱応力および変形におよぼす 予熱之層間温度の影響について検討する.なお解析は層

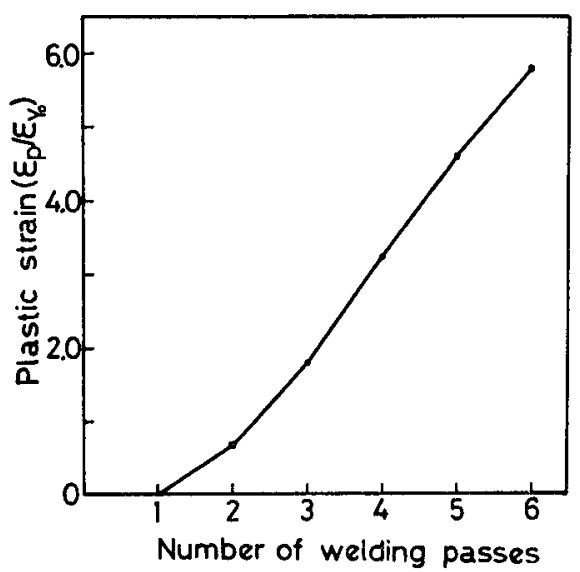

Fig. 14. Relation between plastic strain on back surface and number of weld passes.

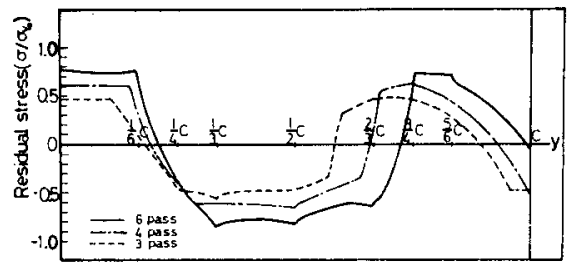

(a) Residual stress distribution

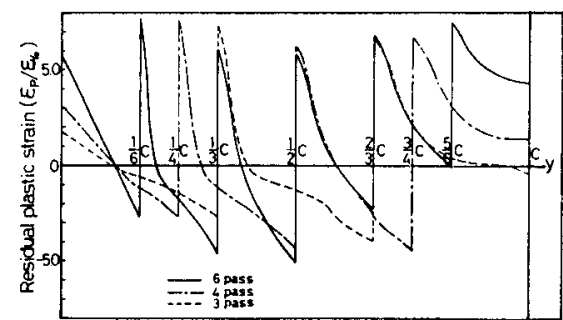

(b) Residuad plastic strain distribution

Fig. 15. Effect of heat input on residual stresses and plastic strains.

間温度約 $150^{\circ} \mathrm{C}$ の場合について行なっている.

Fig. 16 (a) (b) には層数の增加にともなう最終層表面 および初層裹面の残留応力值抒よび塑性ひずみ量の変化 する様子を示している. 図中実線は層間温度が $150^{\circ} \mathrm{C}$ の場合, 破線は層間温度 $0^{\circ} \mathrm{C}$ ののである。な拓 (a) は溶接線江直角方向 ( $x$ 方向) 断面, 図 (b) は溶接線方 向（z方向）断面に関してのあのである.とれより表 面，裹面を問わず，層間温度が高い場合の方が 残留応 力, 塑性ひずみ量ともに小さくなっている. 水素の拡散 および硬化組織の生成という観点から予熱は溶接割れ防 止の有效な手段であることはよく知られた事実である が，残留応力あるいは塑性ひずみ量の点からす予熱はあ る程度有效であるととがわかる。 


\section{4 溶接金属の降状強度の影響}

これまでの解析例は溶接金属の降伏強度が $28.7 \mathrm{~kg} /$ $\mathrm{mm}^{2}$ (Fig. 2 の材料 1) の場合についてのあのである が次洚伏強度が 3 倍の $81.1 \mathrm{~kg} / \mathrm{mm}^{2}$ (Fig. 2 の材料 2 ) の場合についての解析結果を示す.

Fig. 17 (a) (b) は層数の増加にともなう最終層表面お よび初層裹面の残留応力值抒よび塑性ひずみ量の变化す る様子を示している，図中破線は降伏強度が $28.7 \mathrm{~kg} /$ $\mathrm{mm}^{2}$ の場合についての向のである. 図の縦軸はそれぞ れの溶接金属の降伏強度に対しての無次元量で示してい る、因（a）をみると初層襄面は4.1項で述べたように 平均温度上昇飞対応した降伏強度に等しい引張応力が 残留するため，初層裹面の残留応力値は溶接金属の降伏 強度にはほとんど影響されないととがわかる．しかし塑 性ひずみ量は降伏強度が高い場合はいちじるしく小さく なっている.いっぽう最終層表面の残留応力は降伏強度

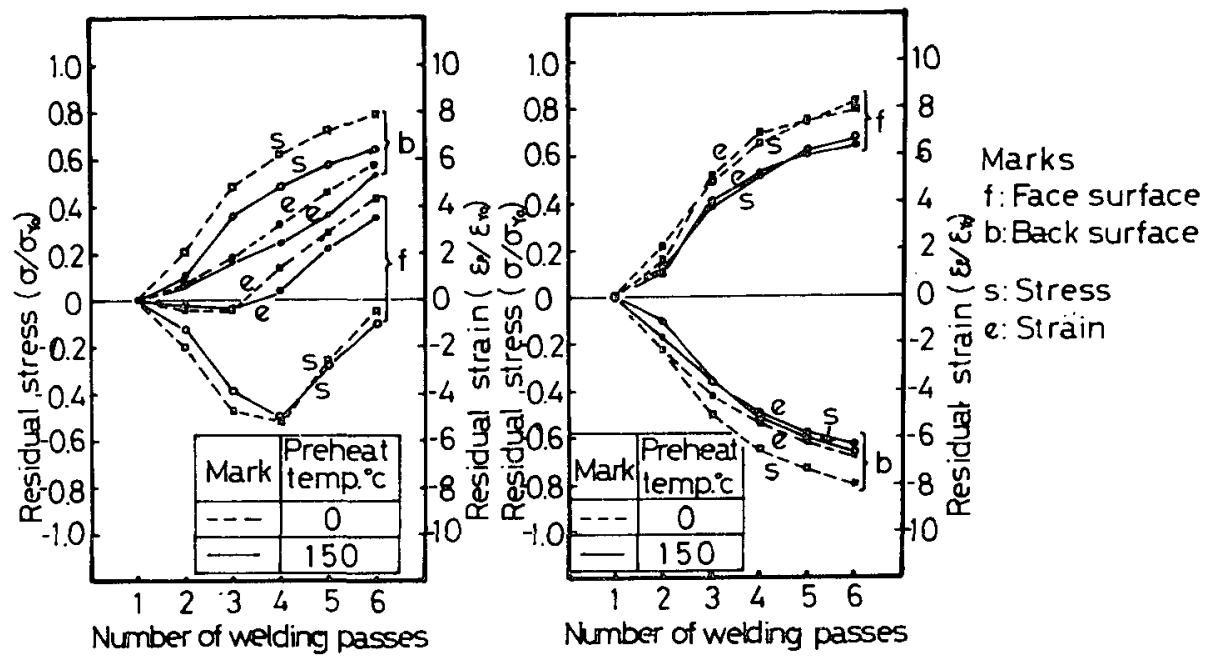

(a) Transverse section

(b) Longitudinal section

Fig. 16. Effects of number of weld passes and interpass temperature on residual stresses and plastic strains.

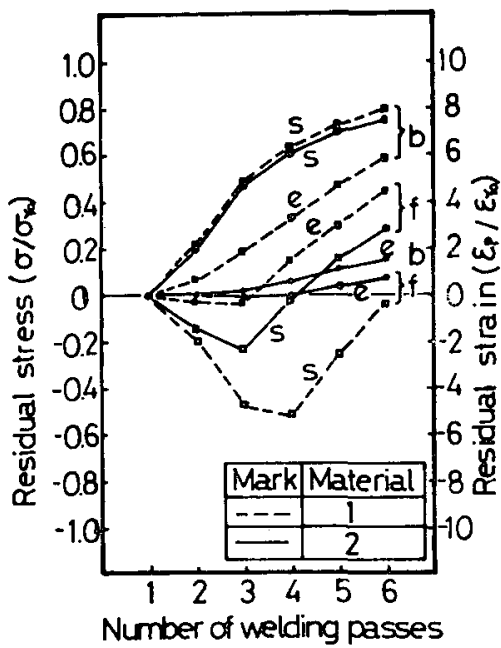

(a) Transverse section

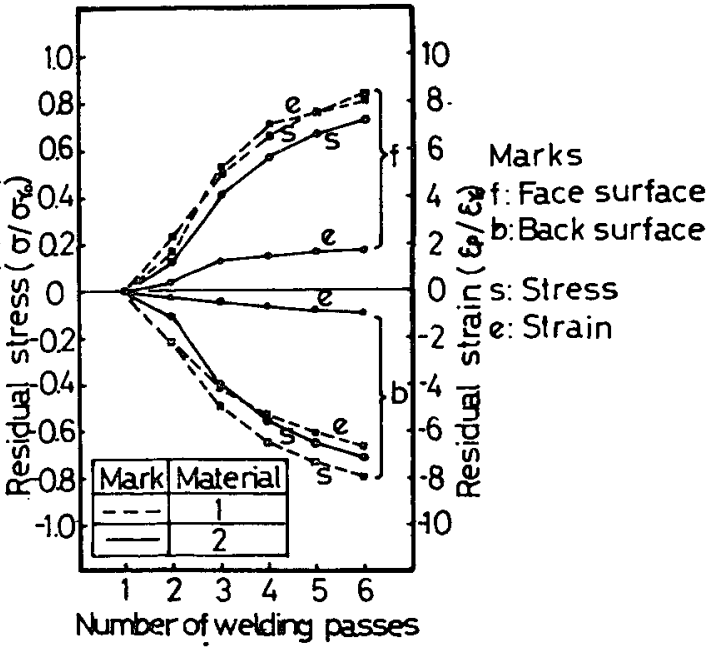

(b) Longitudinal section

Fig. 17. Effects of number of weld passes and yield strength on residual stresses and plastic strains. 
が高い場合は低い場合に比べて角変形が小さいため引張 側となっている。

また図（b）の場合は裏面，表面ともに平均温度上异に 対応した降伏強度に等しい応力が残るため, 残留応力值 はほとんど変わらないが，塑性ひずみ量は降伏強度が高 い場合は非常に小さくなっている.

\section{5. 角変形量と塑性ひずみの関係}

Fig. 18 は溶接線直角方向断面における最終角変形量 と層数の関係を示したもので，角変形量は各層の厚さ $4 \mathrm{~mm}$, 巾 $11 \mathrm{~mm}$ であるとして曲率から計算している。 因の実線之破線は材料 1 (Fig. 2 参照) で層間温度が それぞれ $0^{\circ} \mathrm{C}$ わよ゙ $150^{\circ} \mathrm{C}$ の場合, 一点銧線は材料 2 (Fig. 2 参照) で層間温度 $0^{\circ} \mathrm{C}$ の場合の結果を示し ている. この計算結果から同じ層数でむ層間温度の高い 方が最終角変形量が小さく，また溶接金属の降伏強度の 高い方が最㣠角変形量が小さいととがわかる。

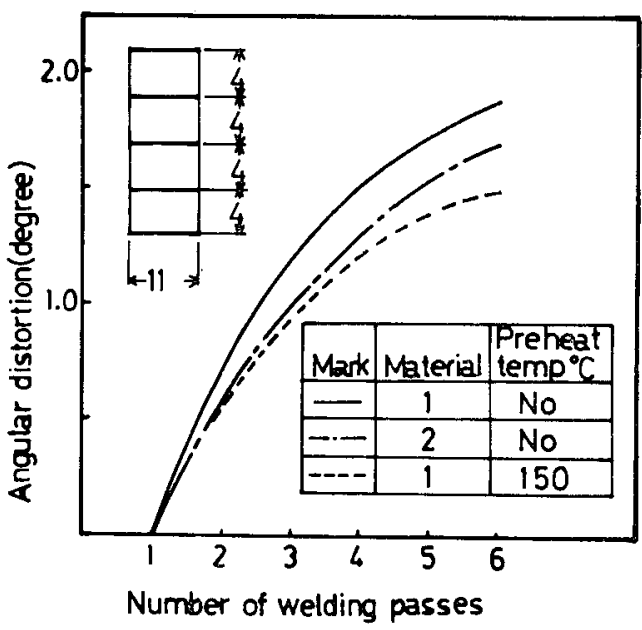

Fig. 18. Effects of number of weld passes, yield strength and interpass temperature on angular distortion.

Fig. 19 は上之同じ条件について最終角変形量之初層 の裏面に生じる残留塑性ひずみ量の関係を示したもので ある. 図からわかるように，同じ角変形量であ塑性ひず み量は条件によって異なり，両者の間に一対一の対応関 係は存在しない。

最近，厚板高張力鋼の多層盛溶接熱影響部に生じる豩 離割れに関連して，Cranfield Test が各所で行なわれ るようになっている（たとえば文献 9). Cranfield Test によって溶接ルート部から割れが発生する場合の力学的 条件は多首盛溶接によるルート部近傍の応力・ひずみ状 態であるがその実測が困難である為，工学的手段として

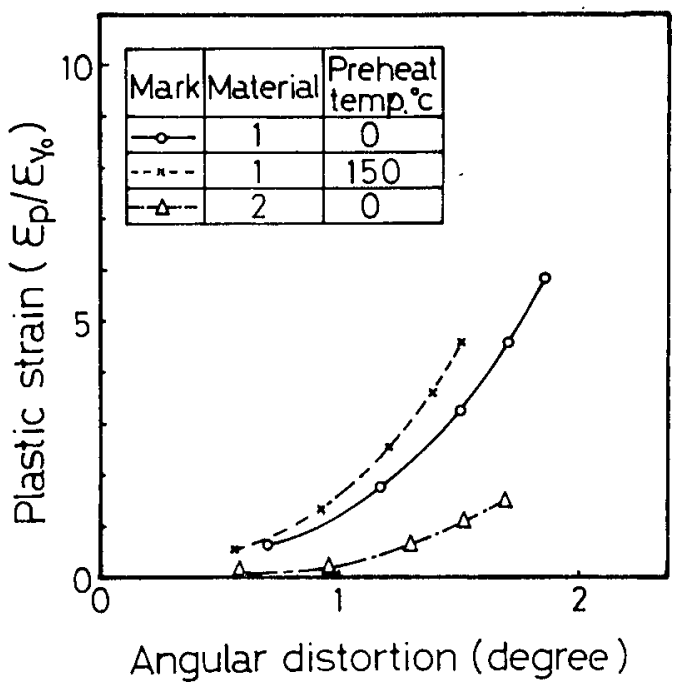

Fig. 19. Relations between plastic strain in back surface and angular distortion under several weld conditions.

割れが発生するまでの角変形量を実測し，てれを割れ防 止の目安とすることが行なわれている．てのような手段 は工学的にはそれなりの意味を持っているであろうが， 最終角変形量之塑性ひずみの関係は Fig. 19 亿示した ように条件によって異なることに注意しなければならな い.

\section{6. 結 論}

本研究の結果を要約すると次の通りである.

1）突合甘継手の多層盛溶接部を簡単な一次元モデル におきかえることにより溶接部の局部的熱応力・ひ ずみ挙動を熱弾塑性計算によって明らかにすること ができた。

2）溶接線に直角方向の残留応力 $\sigma_{x}$ は初層の裏面で は引張応力である，その大きさは，各層の溶接入熱 に上るのど断面平均温度上昇における溶接金属の降 伏応力に等しく，層数が增すほど大きくなる．表面 の $\sigma_{x}$ は層数の小さい間は圧縮応力であるが，層数 が増す之引張応力に移る. (Fig. 11(a))

3）溶接線方向および直角方向の残留応力はいずれも 最終層のすぐ前の層の表面付近に拈いて大きな引張 応力となる. (Fig. 11)

4）多層盛溶接で生じる残留応力には前首までに生じ ていた残留応力の影響はほとんぞない（Fig.6)

5）溶接線江直角方向の残留塑性ひずみは各層の裹面 で大きな引張塑性ひずみとなる.（Fig. 13 (a))

6）同一のど厚の溶接を行なう場合は大入熱小数盛り の溶接を行なう方が残留応力・塑性ひずみともに 
小さくなる. (Fig. 15)

7) 角変形量と初層裹面に生じる残留塑性ひずみの関 係は，層間温度や溶接金属の降伏強度によって異な り，両者に一対一の対応関係は存在しない.

(Fig. 19)

謝 辞 本研究に対して有益など討論を賜わった溶接 学会溶接構造研究委員会わよび日本造船学会溶接研究委 員会第 2 分科会委員各仙に対して深く謝意を表します。

\section{窨 文 献}

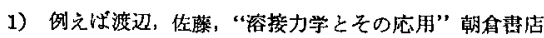

2) Y. Ueda; Analysis of Thermal Elastic-Plastic Stress and Strain during Welding" IIW X-616-71

3）滕田, 野本: “熱弹望性問题に関する研究（その1）”日本造船学 会諭文集，第130号 (1971)

4）过：“一次元温度分布を有する短形板の熱弾塑性応力問題比関する 两宪”，造船協会論文集，第115号（1964）

5）佐藤，伀井：“アーク浴接継手の收縮過程江関する研究(第 1 報)”, 本點, 第35巻 (1966)

6）小林，四川，田村：“高佷力鋼の多層溶接部に特ける再熱製れにつ いて”，本会满演概要，第1集 (1972)

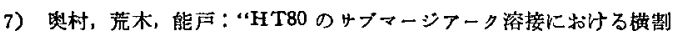
れについて”，本会講演概要，第10集 (1972)

8）荒木，能戸，原沢：“HT80の多層すみ内肉溶接部に発生する割れに ついて，本会講湍概要，第10集（1972）

9）浮由，荒木，永尾，原沢：“多層すみ内溶接部に発生する制れにつ いて”, 本会辣演概要, 第11集 (1972)

\section{次号予 告}

論文

ろう付用アミン塩酸塩フラックスの作用機構に関する研究

$\left\{\begin{array}{lll}\text { 木 } & \text { 原 } & \text { 博 } \\ \text { 大 } & \text { 畧 }\end{array}\right.$

鉄鋼溶接部における硫化物の挙動之凝固割れ（第 3 報）

$\mathrm{Pb}$ の Hot dip coating に関する研究（第 2 報）

金属浴浸漬急冷による銅材溶接継手の疲れ強さ改善（第 5 報）….............. 保

痋れ割れによるぜい性破壊発生の研究

西昆安弘

梶 本 勝 也

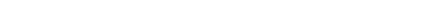

テーパかたさ試験法確立のための検討

融点近傍飞おける溶融金属の粘性と昖散粘性と表面張力などとの間の関係…...

鉄鋼溶着金属の異常破面に関する研究（第 2 報）

\section{資料}

はんだ绝性について 